\title{
Factors associated with antiretroviral treatment failure among people living with HIV on antiretroviral therapy in resource- poor settings: a systematic review and metaanalysis
}

Yishak Lailulo ${ }^{1 \dagger}$, Marcel Kitenge ${ }^{1,2 \dagger}$, Shahista Jaffer ${ }^{1}$, Omololu Aluko ${ }^{1}$ and Peter Suwirakwenda Nyasulu ${ }^{1,3^{*}}$ (i)

\begin{abstract}
Background: Despite the increase in the number of people accessing antiretroviral therapy (ART), there is limited data regarding treatment failure and its related factors among HIV-positive individuals enrolled in HIV care in resource-poor settings. This review aimed to identify factors associated with antiretroviral treatment failure among individuals living with HIV on ART in resource-poor settings.

Methods: We conducted a comprehensive search on MEDLINE (PubMed), Excerpta Medica Database (EMBASE), Cochrane Central Register of Controlled Trials (CENTRAL), World Health Organization's (WHO's) library database, and Latin American and Caribbean Health Sciences Literature (LILACS). We included observational studies (cohort, casecontrol, and cross-sectional studies) where adolescents and adults living with HIV were on antiretroviral treatment regardless of the ART regimen. The primary outcomes of interest were immunological, virological, and clinical failure. Some of the secondary outcomes were $\mathrm{mm}^{3}$ opportunistic infections, WHO clinical stage, and sociodemographic factors. We screened titles, abstracts, and the full texts of relevant articles in duplicate. Disagreements were resolved by consensus. We analyzed the data by doing a meta-analysis to pool the results for each outcome of interest.

(Continued on next page)
\end{abstract}

\footnotetext{
* Correspondence: pnyasulu@sun.ac.za

${ }^{\dagger}$ Yishak Lailulo and Marcel Kitenge contributed equally to this work.

'Division of Epidemiology and Biostatistics, Department of Global Health,

Faculty of Medicine and Health Sciences, Stellenbosch University, Cape

Town, South Africa

${ }^{3}$ Division of Epidemiology \& Biostatistics, School of Public Health, Faculty of Health Sciences, University of the Witwatersrand, Johannesburg, South Africa

Full list of author information is available at the end of the article
}

C C The Author(s). 2020 Open Access This article is licensed under a Creative Commons Attribution 4.0 International License, which permits use, sharing, adaptation, distribution and reproduction in any medium or format, as long as you give appropriate credit to the original author(s) and the source, provide a link to the Creative Commons licence, and indicate if changes were made. The images or other third party material in this article are included in the article's Creative Commons. licence, unless indicated otherwise in a credit line to the material. If material is not included in the article's Creative Commons licence and your intended use is not permitted by statutory regulation or exceeds the permitted use, you will need to obtain permission directly from the copyright holder. To view a copy of this licence, visit http://creativecommons.org/licenses/by/4.0/ The Creative Commons Public Domain Dedication waiver (http://creativecommons.org/publicdomain/zero/1.0/) applies to the data made available in this article, unless otherwise stated in a credit line to the data. 


\begin{abstract}
(Continued from previous page)
Results: Antiretroviral failure was nearly 6 times higher among patients who had poor adherence to treatment as compared to patients with a good treatment adherence $(\mathrm{OR}=5.90,95 \% \mathrm{Cl} 3.50,9.94$, moderate strength of evidence). The likelihood of the treatment failure was almost 5 times higher among patients with CD4 < 200 cells/ $\mathrm{mm}^{3}$ compared to those with CD4 $\geq 200 \mathrm{CD} 4$ cells $/ \mathrm{mm}^{3}$ (OR $=4.82,95 \% \mathrm{Cl} 2.44,9.52$, low strength of evidence). This result shows that poor adherence and CD4 count below $<200$ cells $/ \mathrm{mm}^{3}$ are significantly associated with treatment failure among HIV-positive patients on ART in a resource-limited setting.
\end{abstract}

Conclusion: This review highlights that low CD4 counts and poor adherence to ART were associated to ART treatment failure. There is a need for healthcare workers and HIV program implementers to focus on patients who have these characteristics in order to prevent ART treatment failure.

Systematic review registration: The systematic review protocol was registered with the International Prospective Register of Systematic Reviews (PROSPERO), registration number: 2019 CRD42019136538.

Keywords: HIV, ART, Immunological failure, Virological failure, Clinical failure, Poor outcome

\section{Background}

Human immunodeficiency virus (HIV) infections are a major global public health concern. In 2019, an estimated 38 million people were living with HIV infection (PLWH) [1]. With new infections, an estimated 1.7 million people became newly infected with HIV in 2019. Sub-Saharan Africa (SSA) remains the most affected region in the world, with about 20.7 million prevalent cases and 730,000 new infections were recorded in 2019, seconded by Asia and the Pacific region with 5.8 million prevalent cases [1]. Although Southern Africa is home to less than $1 \%$ of the global population, the region has more than a fourth of all HIV infection in the world, with 300,000 acquired immune deficiency syndrome (AIDS)-related deaths registered in the same year in SSA [1].

Although anti-retroviral therapy (ART) coverage in this region has rapidly increased over the past decade [2]. The greatest gains in access to ART occurred in SSA [3]. In 2019, only 15 million (73\%) PLHIV in the region were accessing ART, while 3.5 million (60\%) in Asia and the Pacific region [1]. Increasing the use of ART has contributed to a prominent decline in HIV-associated morbidity and death/mortality in SSA [2]. United Nations program on HIV/AIDS (UNAIDS) has suggested universal targets for the year 2020 (90-90-90), which means diagnosing $90 \%$ of all PLHIV who should know their status (PLHIV), initiating antiretroviral treatment (ART) for $90 \%$ of those diagnosed with HIV infection, and attaining an undetectable viral load in $90 \%$ of those on ART [4]. Significant progress has been made in achieving that goal. Globally, PLWH accessing ART has increased from 21.7 million in 2015 to 25.4 million in 2019 , an increase from 45 to $67 \%$ of all PLHIV $[3,5]$.

\section{Antiretroviral treatment failure}

Patients with ART failure are increasingly encountered in resource-limited settings, while recent estimates suggest only $2 \%$ of those currently on ART are on second-line [6], a far greater number is likely to be failing virologically but have not switched to an alternative regimen. Furthermore, an increase in the coverage of ART use among PLHIV, which has resulted in an increase in the number of individuals failing first-line ART, and therefore, the magnitude increases with prolonged use of ART. The WHO predicted earlier on that 500,000 and 800,000 PLWH on the first-line combination of ART will require a switch to the second-line therapy by 2010 [2]. However, the burden of treatment failure is not well-documented, while there is a large scale of ARV in resource-limited countries. Metaanalysis data showed that the rate of the treatment failure for the first-line was $6.08 \%$ globally; however, the study noted a substantial heterogeneity across regions with $7.10 \%$ in Africa and $2.55 \%$ in Asia [3].

A retrospective cohort study done in South Africa found that among patients on non-nucleotide reverse transcriptase inhibitor (NNRTI)-based ART, after a median of 15 months on ART treatment, 19\% had failed virologically and immunologically [6]. Studies in East Africa have shown a high prevalence of immunologic failure ranging from 8 to $57 \%$ among clients on the firstline ART [7-9].

Treatment failure is typically measured in three ways in poor-resource settings: (i) clinically, as evidenced by disease progression; (ii) immunologically, as evidenced by trends in CD4 counts over time; and (iii) virologically, as evidenced by measurement of HIV RNA levels. In 2013, WHO recommended viral load testing as the preferred monitoring approach to diagnose and to confirm ARV treatment failure [10].

\section{Factors associated with treatment failure}

Earlier studies have emphasized a number of factors that may be associated with virological suppression in ART; these are reasons for testing: routine testing, suspected treatment failure, and repeat testers after suspected failure [9-11]. While a significant number of studies have found that treatment failure is significantly associated with young 
age, unsatisfactory adherence, low hemoglobin, history of lost to follow-up, being male and educational status, and treatment regimen [12-14], some studies have recognized low baseline CD4 cell count, rate of CD4 decline, prior exposure to ART and treatment interruptions, and nonadherence as determinants of treatment failure $[15,16]$.

In 2016, WHO most recent guideline defined a clinical failure as a new or recurrent clinical event indicating severe immunodeficiency (WHO clinical stage 4 condition) after 6 months of effective treatment. Immunological failure is defined as CD4 count at or below 250 cells $/ \mathrm{mm}^{3}$ following a clinical failure or persistent CD4 levels below 100 cells $/ \mathrm{mm}^{3}$, and virological failure is defined as viral load above 1000 copies $/ \mathrm{mL}$ based on two consecutive viral load measurements in 3 months, with adherence support following the first viral load test [17]. The results from a previous study have confirmed that low baseline CD4 cell count, particularly $<100$ cells $/ \mathrm{mm}^{3}$, and history of loss to follow-up are risk factors for immunological discordance [18]. Independent risk factors associated with virological failure were being followed-up at the semirural center, having experienced unstructured treatment interruptions, and having low CD4 counts at enrolment [19].

Gender, time on ART, baseline CD4 T cell count, WHO stage, ART regimen, adherence, and TB co-infection were associated with viral suppression [20]. The history of the antiretroviral use before starting ART, change of antiretroviral therapy due to toxicity, opportunistic infections while on ART treatment, level of CD4 + lymphocytes below 100 cells $/ \mathrm{ml}$ at start of ART, adherence, and clinical stage were independently associated with virological failure [21]. Age younger than 40 years was also associated with virologic failure [22]. The relative contribution of the main predictors to virological failure may differ across settings and population groups and context. Thus, specific data are critical to the carrying out of corrective measures.

\section{Importance of the review}

Viral load testing provides early and accurate indications of the treatment failure and the need to switch from the first-line to second-line drugs, thereby reducing the accumulation of the drug-resistant mutations and improving clinical outcomes [23].

However, regular access to routine viral load testing remains a challenge due to the high cost. In such a situation, clinical and immunological monitoring is used for detecting treatment failure [24-27]. The number of people accessing ART has significantly increased in many poor resource settings [28]. Hence, it is significant to sustain treatment success and limit the development of treatment failure. For the timely detection of treatment failure, WHO reconfirmed the use of viral load testing as the gold standard test to monitor patients' response to ART [29]. Where the viral load is not routinely available, CD4 count and clinical monitoring should be used to diagnose treatment failure. In spite of a large number of patients receiving ARTs in lowand middle-income countries (LMICs) and poor settings, there are few reports on ART outcomes in these settings. Identifying baseline predictors of the first-line ART outcome among PLWH on ART in LMICs where access to viral load testing is limited is of paramount importance.

The technique and accuracy of identifying treatment failure in poor settings are important but challenging. Delayed detection of ART failure may increase drug toxicity may lead to the increase of drug resistance related with mutations (further controlling treatment choices) and may result in increased morbidity and mortality. Early detection of treatment failure is crucial to ensure the effectiveness of the first-line therapy [6].

The main objective of this review was to identify factors associated with antiretroviral treatment failure among PLWH on ART in resource-poor settings.

\section{Objective \\ Primary objective}

The primary objective of the study was to determine the clinical, immunological, and virological factors associated with antiretroviral treatment failure among PLWH in resource-poor settings.

\section{Secondary objective}

The secondary objective of the study is to identify the socio-demographic and economic factors associated with antiretroviral treatment failure among PLWH among PLWH in resource-poor settings.

\section{Methods}

The methods of this systematic review and meta-analysis were reported as per the Preferred Reporting Items for Systematic Review and Meta-Analysis Protocols (PRIS MA-P) checklist [30]. We registered the protocol for this systematic review on the International Prospective Register of Systematic Reviews (PROSPERO) with a registration number: CRD42019136538.

\section{Criteria for considering studies for review Types of studies}

We included all types of observational studies including prospective/retrospective or ambi-directional cohort studies, case-control studies, population-based/nested or hospitalbased case-control studies, and cross-sectional studies. Interventional studies were excluded from this review.

\section{Types of participants}

Adolescents and adults living with HIV who were on ART for $\geq 6$ months, regardless of the regimen. Only participants with documented baseline CD4 and VL were considered for this systematic review. 


\section{Type of outcome}

\section{Primary outcome}

Treatment failure was defined as follows:

\section{Virological failure}

Virological failure is defined as a plasma viral load above 1000 copies/ml based on two consecutive viral load measurements after 3 months, with adherence support. A viral load test is a measurement of the amount of HIV in a sample of the blood. This is usually reported as the number of copies per milliliter (copies $/ \mathrm{mm}^{3}$ ) [17].

\section{Immunological failure}

Immunological failure is defined as a fall in CD4 count to the baseline (or below) or persistent CD4 levels below 100 cells $/ \mathrm{mm}^{3}$. The CD4 lymphocyte count is an excellent indicator of how healthy the immune system is. These are a type of white blood cells, called $\mathrm{T}$ cells, which move throughout the human body to find and destroy bacteria, viruses, and other invading germs. The CD4 cell count is indicated in cells per $\mathrm{mm}^{3}$, and it is measured by taking a blood sample [17].

\section{Clinical failure}

Clinical failure is defined as the occurrence of new opportunistic infections (excluding immune reconstitution inflammatory syndrome [IRIS]) and/or other clinical evidence of HIV disease progression during therapy. AIDSdefining illnesses (opportunistic infections) are those which the Centers for Disease Control and Prevention (CDC) have classified as being directly associated with advanced HIV infection. We considered the common diseases, which are pneumonia, TB, lymphoma, and cryptococcosis [17].

\section{Secondary outcome}

Secondary outcomes for this study are all the predictors' variables that contribute to treatment failure. The following information was collected if measured at baseline: CD4 cells (cells $/ \mathrm{mm}^{3}$ ), viral load (copies/ml), WHO clinical, tuberculosis, opportunistic infection, treatment regimen (NRTI or NNRTI), BMI, weight, study site (rural versus urban), gender, age, educational status, employment status, marital status, and spouse HIV serostatus.

\section{Inclusion and exclusion criteria Included studies}

Participants in the study were (1) those who had been on ART for $\geq 6$ months and (2) those who had documented CD4 cell count and viral load measurement at baseline and 6 months.

\section{Excluded studies}

All studies with participants who had pregnancy history the past 6 months while on treatment and at 6 months' visit or had missing values of CD4 cell count and viral load at baseline and 6 months' visit were excluded.

\section{Search methods for identification of the studies}

We conducted a comprehensive search on 5 databases from December 1, 2000, to November 2019. With assistance from an information specialist, we searched in the following databases: MEDLINE (Pubmed), EMBASE (OVID), LILACS (BIREME), Science Citation Index Expanded (SCI-EXPANDED, Web of Science), Social Sciences citation index (SSCI, Web of Science), Conference Proceedings Citation Index-Social Science \& Humanities (CPCI-SSH, Web of Science), and Cinahl (EBSCOHost). A detailed search strategy is provided in Appendix 1. A hand search of citations from selected studies was conducted to identify additional studies missing from the original electronic searches.

\section{Screening and assessments of study eligibility}

All potential studies were imported into Covidence (Covidence systematic review software, Veritas Health Innovation, Melbourne, Australia), and two review authors (YL and SJ) independently screened the titles and abstracts. Both authors also assessed full-text eligibility.

All published full-text articles, abstracts, and brief reports were included, and provided/available complete data were elicited from them. The disagreements between the two authors who assessed study eligibility were resolved by discussion and consensus.

\section{Data extraction, management, and analysis}

Data from the full-text articles were extracted by two independent review authors (YL, SJ) using a standardized pre-piloted data extraction form. A third reviewer (MK, $\mathrm{PN})$ checked whether the extracted data were correct. Extracted data were categorized into four main headings: general information, socio-demographic and economic characteristics of participants, and clinical and immunological information of the participant. In case of missing information, we clarified the conducted study or the studies that had relevant data, which were not reported in the published manuscript, and we contacted the authors for additional information.

\section{Risk of bias and quality of evidence}

Two authors independently assessed the risk of bias in each study by examining the study population, study attrition, prognostic factor measurement, outcomes measurement, study confounding, and statistical reporting (YL and OA). They coded studies as at high, medium, low, or unclear risk of bias for each of these features 
using the Quality in Prognosis Studies tool (QUIPS tool) [31]. Finally, we assessed the quality of the evidence using the Grading of Recommendations Assessment Development and Evaluations (GRADE) approach using the five criteria of the GRADE system.

\section{Statistical analysis}

For the studies that were relatively homogeneous in terms of methodology and outcomes, a meta-analysis of the data was performed. Sufficiently, similar data was pooled using the inverse variance approach to accommodate crude and adjusted odds ratios, where possible. Additionally, the meta-analysis was summarized using pooled estimates, the 95\% confidence interval, and the between-study variance was estimated using $\mathrm{Tau}^{2}$. We extracted all unadjusted and adjusted measures of the association from all included studies and converted effect sizes as necessary to possible selection bias, thus allowing us to use the data from as many studies as possible. We anticipated that results from multivariate analyses would have been reported as odds ratios (ORs), risk ratios (RRs), and hazard ratios (HRs), if so, we would use ORs as the common measure of the association, using RRs and HRs to estimates ORs at a particular time point [32]. Furthermore, measures of effect were analyzed using RevMan statistical software for systematic reviews. Statistical heterogeneity was quantified using the $I^{2}$ statistic [33]. If the $I^{2}$ statistic is high (75 to $100 \%$ - as suggested by Higgins et al.) indicating high heterogeneity [33], a random effect model was used.

\section{Results}

\section{PRISMA flow chart}

We retrieved 2418 articles regarding treatment failure among ART users in poor resource setting as identified in MEDLINE (PubMed); EMBASE (OVID); LILACS (BIREME); Science Citation Index Expanded (SCI-EXPANDED, Web of Science), Social Sciences citation index (SSCI, Web of Science), and Conference Proceedings Citation Index-Social Science \& Humanities (CPCI$\mathrm{SSH}$, Web of Science), and CINAHL (EBSCOHost). These are shown in Fig. 1.

Of these initial articles, 3 articles were duplicates; 2158 articles were excluded after reviewing their titles and abstracts and confirmed irrelevant to this review. Thus, 237 potential full-text articles were assessed for eligibility, which resulted in further exclusion of 100 articles.

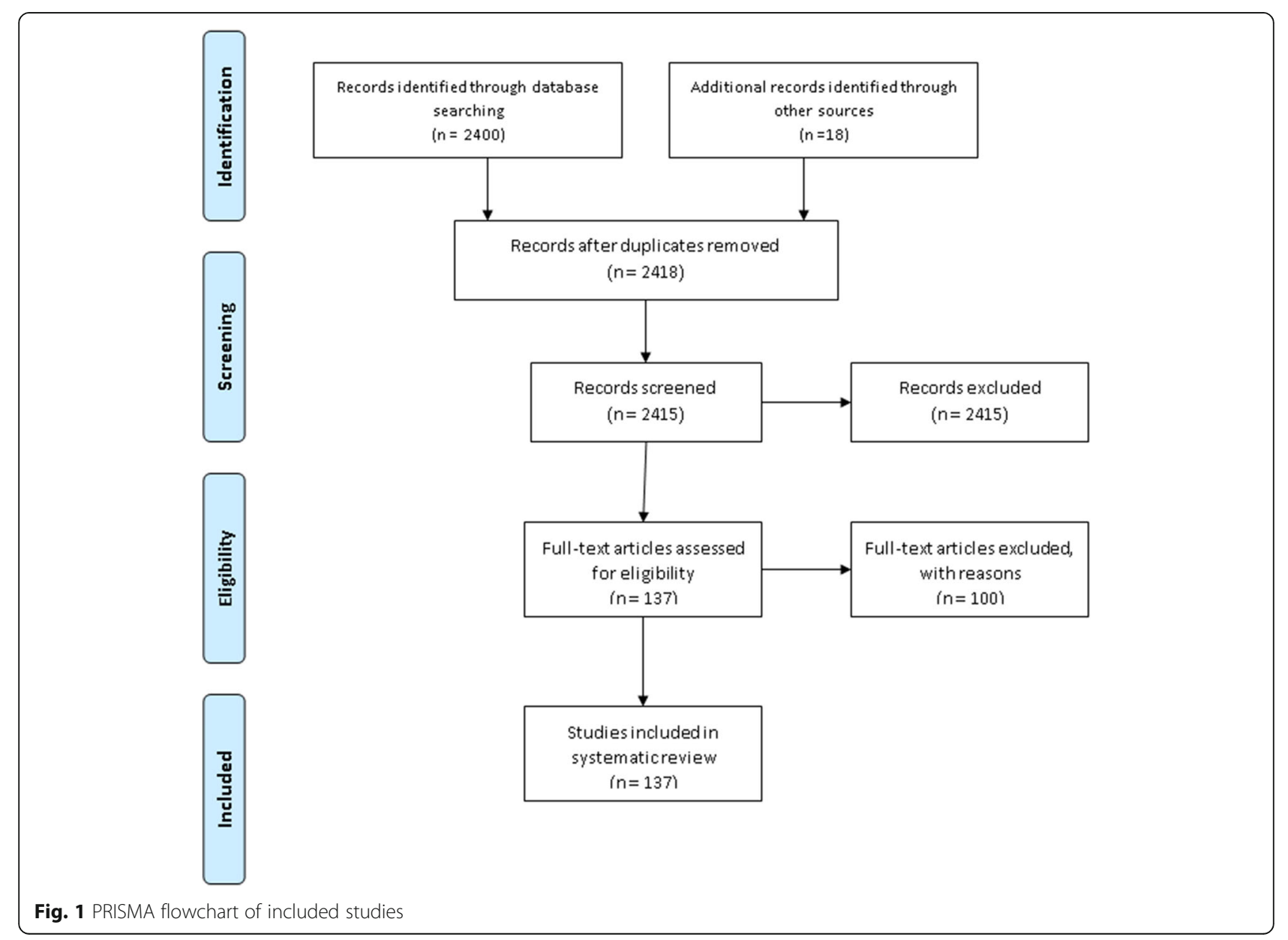


57 had wrong outcomes, 19 assessed HIV drug-resistant mutations, 12 had the wrong study design, 7 had a wrong patient population, 2 were not in English 1 and was a duplicate, 1 had a wrong setting, and 1 was pediatric population. Finally, 137 studies met the eligibility criteria. These are shown in Table 1.

\section{Meta-analysis}

The association between adherence and treatment failure was based on six cross-sectional studies [14, 35, 37, 40, 42, 47]. The results as presented in Fig. 2 showed a strong relationship between treatment failure and poor treatment adherence. The odds of treatment failure were nearly 6 times higher among patients who had poor adherence $(\mathrm{OR}=5.90,95 \% \mathrm{CI} 3.50,9.94$, moderate strength of evidence). The test statistics, however, showed a substantial heterogeneity $\left(I^{2}=65 \%\right.$ and $\left.p=0.02\right)$.

Similarly, the association between poor adherence and treatment failure was examined using four cohort studies [36, 39, 41, 46]. The results as presented in Fig. 3 showed that the hazard ratio of treatment failure was nearly 2.5 higher among patients who had poor adherence $(\mathrm{HR}=$

Table 1 Characteristics of included studies

\begin{tabular}{|c|c|c|c|c|c|c|c|}
\hline References & $\begin{array}{l}\text { Year of } \\
\text { publication }\end{array}$ & Study design & Country & Patients groups & ART used & $\begin{array}{l}\text { Sample } \\
\text { size }\end{array}$ & $\begin{array}{l}\text { Number of } \\
\text { Treatment failure }\end{array}$ \\
\hline Babo et al. [34] & 2017 & Case-control study & Ethiopia & Adult & $\begin{array}{l}\text { Stavudine vs. Zidovudine } \\
\text { Nevirapine vs. Efavirenz }\end{array}$ & 307 & 230 \\
\hline Bayu et al. [35] & 2017 & Case-control study & Ethiopia & $\begin{array}{l}\text { Adults aged } \geq \\
15 \text { years }\end{array}$ & $\begin{array}{l}\text { D4T-based } \\
\text { AZT-based } \\
\text { TDF-based }\end{array}$ & 306 & 160 \\
\hline Bilcha et al. [36] & 2019 & $\begin{array}{l}\text { Retrospective } \\
\text { cohort study }\end{array}$ & Ethiopia & Adult & $\begin{array}{l}\text { Nevirapine-based } \\
\text { Efavirenz-based }\end{array}$ & 396 & 47 \\
\hline Bisson et al. [37] & 2008 & Case-control study & Botswana & $\begin{array}{l}\text { Adults older than } \\
18 \text { years }\end{array}$ & NR & 302 & 247 \\
\hline Fatti et al. [38] & 2019 & $\begin{array}{l}\text { Prospective cohort } \\
\text { study }\end{array}$ & $\begin{array}{l}\text { South } \\
\text { Africa }\end{array}$ & $\begin{array}{l}\text { Adults aged } \geq \\
18 \text { years }\end{array}$ & NRTI and NNRTI & 1901 & 60 \\
\hline Ford et al. [39] & 2010 & $\begin{array}{l}\text { Observational } \\
\text { cohort }\end{array}$ & $\begin{array}{l}\text { South } \\
\text { Africa }\end{array}$ & Adult & EFV, NVP, and other & 207 & 32 \\
\hline Gunda et al. [40] & 2019 & Case-control study & Tanzania & Adult & $\begin{array}{l}\text { AZT/3TC/EFV, AZT/3TC/NVP, } \\
\text { D4T/3TC/NVP, TDF/3TC/EFV }\end{array}$ & 197 & 24 \\
\hline Haile et al. [41] & 2016 & $\begin{array}{l}\text { Retrospective } \\
\text { cohort study }\end{array}$ & Ethiopia & $\begin{array}{l}\text { Adult ( } \geq 15 \text { years } \\
\text { old) }\end{array}$ & $\begin{array}{l}1 \mathrm{a}(\mathrm{d} 4 \mathrm{~T}+3 \mathrm{TC}+\mathrm{NVP}), 1 \mathrm{~b}(\mathrm{~d} 4 \mathrm{~T} \\
+3 T C+\mathrm{EFV}) \\
1 \mathrm{c}(\mathrm{AZT}+3 \mathrm{TC}+\mathrm{NVP}) \\
1 \mathrm{~d}(\mathrm{AZT}+3 \mathrm{TC}+\mathrm{EFV}), \\
1 \mathrm{e}(\mathrm{TDF}+3 \mathrm{TC}+\mathrm{EFV}), 1 \mathrm{f}(\mathrm{TDF} \\
+3 T C+\mathrm{NVP})\end{array}$ & 4809 & 113 \\
\hline Hailu et al. [42] & 2018 & $\begin{array}{l}\text { Retrospective } \\
\text { follow-up study }\end{array}$ & Ethiopia & $\begin{array}{l}\text { Adults ( } \geq 20 \\
\text { years) }\end{array}$ & $\begin{array}{l}\text { TDF 3TCEFV/NVP, AZT 3TC } \\
\text { NVP/EFV, } \\
\text { D4T 3TC NVP/EFV, ABC 3TC } \\
\text { EFV }\end{array}$ & 260 & 30 \\
\hline Hassan et al. [14] & 2014 & $\begin{array}{l}\text { Cross-sectional } \\
\text { study }\end{array}$ & Kenya & Adult & $\begin{array}{l}\text { Zidovudine-based and } \\
\text { Stavudine-based }\end{array}$ & 232 & 57 \\
\hline Izudi et al. [43] & 2016 & $\begin{array}{l}\text { Retrospective } \\
\text { cohort }\end{array}$ & Uganda & Adult & & 383 & 28 \\
\hline Karade et al. [44] & 2016 & $\begin{array}{l}\text { Cross-sectional } \\
\text { studies }\end{array}$ & India & Adult & $\begin{array}{l}\mathrm{AZT}+3 \mathrm{TC}+\mathrm{NVP}, \mathrm{AZT}+ \\
3 \mathrm{TC}+\mathrm{EFV} \\
\mathrm{TDF}+3 \mathrm{TC}+\mathrm{NVP}, \mathrm{TDF}+ \\
3 \mathrm{TC}+\mathrm{EFV} \\
\mathrm{d} 4 \mathrm{~T}+3 \mathrm{TC}+\mathrm{NVP} / \mathrm{EFV}\end{array}$ & 844 & 104 \\
\hline Lay et al. [45] & 2017 & $\begin{array}{l}\text { Retrospective } \\
\text { cohort study }\end{array}$ & Cambodia & $\begin{array}{l}\text { Adult ( } \geq 18 \text { years } \\
\text { old) }\end{array}$ & $\begin{array}{l}\mathrm{d} 4 \mathrm{~T} / 3 \mathrm{TC} / \mathrm{EFV}, \mathrm{d} 4 \mathrm{~T} / 3 \mathrm{TC} / \mathrm{NVP} \\
\mathrm{AZT} / 3 \mathrm{TC} / \mathrm{EFV}, \mathrm{AZT} / 3 \mathrm{TC} / \mathrm{NVP} \\
\text { Other }\end{array}$ & 3581 & 137 \\
\hline $\begin{array}{l}\text { Ndahimana et al. } \\
{[46]}\end{array}$ & 2016 & $\begin{array}{l}\text { Retrospective } \\
\text { cohort }\end{array}$ & Rwanda & $\begin{array}{l}15 \text { years and } \\
\text { older }\end{array}$ & NRTIs, NNRTIs, and PIs & 828 & 70 \\
\hline Ahmed et al. [47] & 2019 & Case-control study & Ethiopia & Adult & $\begin{array}{l}\mathrm{d} 4 \mathrm{t}+3 \mathrm{TC}+\mathrm{NVP}, \mathrm{AZT}+3 \mathrm{TC} \\
+\mathrm{NVP} \\
\mathrm{AZT}+3 \mathrm{TC}+\mathrm{EFV}, \mathrm{TDF}+3 \mathrm{TC} \\
+\mathrm{EFV} \\
\mathrm{TDF}+3 \mathrm{TC}+\mathrm{NVP}\end{array}$ & 308 & 199 \\
\hline
\end{tabular}




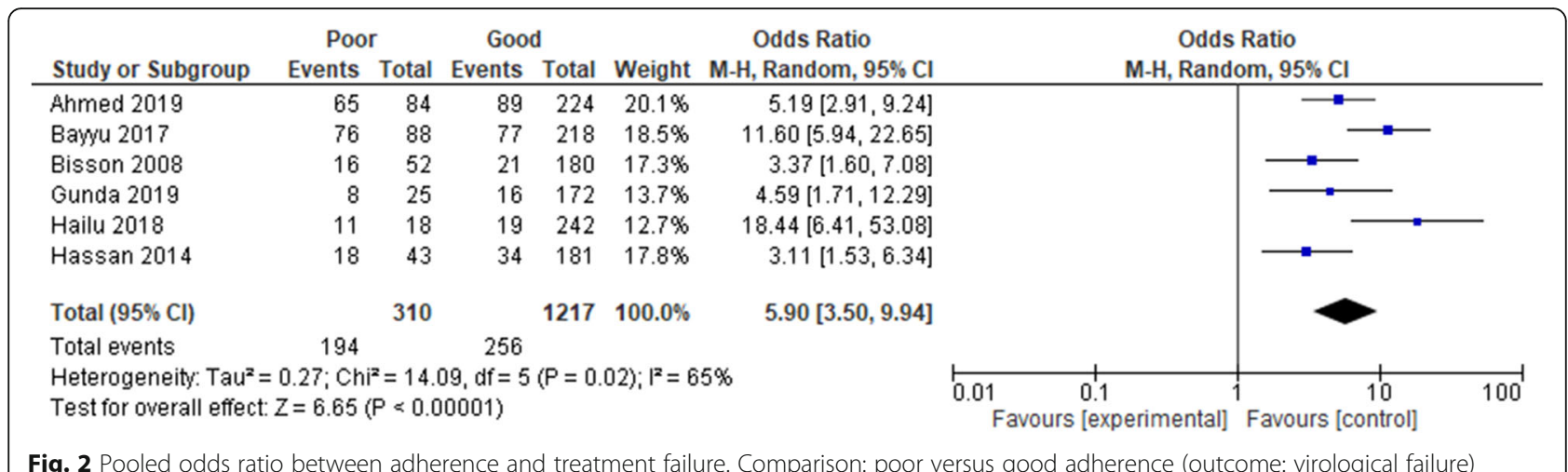

Fig. 2 Pooled odds ratio between adherence and treatment failure. Comparison: poor versus good adherence (outcome: virological failure)

2.46, 95\% CI 1.72, 3.51, high strength of evidence). The result of test statistics showed no heterogeneity $\left(I^{2}=0 \%\right.$ and $p=0.90)$. Here too, a random effect meta-analysis model was used to determine the association with the outcome.

Furthermore, the association between $\mathrm{CD} 4$ and treatment failure was examined by using three crosssectional studies [35, 40, 47]. The results as presented in Fig. 4 showed that treatment failure was strongly associated with CD4 count. The odds of treatment failure were nearly 5 times higher among patients who had a CD4 cell count of 200 cells $/ \mathrm{mm}^{3}$ (OR $=4.82,95 \%$ CI 2.44 , 9.52, low strength of evidence). However, the test statistics showed substantial heterogeneity $\left(I^{2}=71 \%\right.$ and $p=$ 0.03). Hence, a random effect meta-analysis model was used to determine the association with the outcome.

Likewise, the association between low CD4 count and treatment failure was also observed using four cohort studies $[36,38,45,46]$. Results presented in Fig. 5 showed that the hazard ratio of treatment failure was nearly 3 times higher among patients who had CD4 lower than 200 cells $/ \mathrm{mm}^{3}(\mathrm{HR}=2.98,95 \%$ CI 2.23, 4.00, moderate strength of evidence). The result of the test statistics showed no evidence of heterogeneity $\left(I^{2}=\right.$ $0 \%$ and $p=0.55)$. A random effect meta-analysis model was used to determine the association with the outcome.

Our study also demonstrated similar findings to the above through data abstracted from two cross-sectional studies [34, 44]. We also found that treatment failure was significantly associated with low CD4 count, where the odds of treatment failure were 1.14 times higher among patients with CD4 lower than 100 cells $/ \mathrm{mm}^{3}$ (OR $=1.14,95 \%$ CI 0.52, 2.47, low strength of evidence). The test statistics showed moderate heterogeneity $\left(I^{2}=\right.$ $49 \%$ and $p=0.75$ ), see Fig. 6 . Consequently, a random effect meta-analysis model was computed to determine the association.

\section{Risk of bias assessment}

Most of the studies had a low risk of bias on prognostic factors that accounted for $125 / 137$, followed by study participants (123/135), statistical analysis and reporting (116/137), and outcome measurement (115/137). Moreover, 109/137 studies had a low risk of bias on study confounding and 103/137 studies had a low risk of bias on study participant attrition. The full table of results is shown in Appendix 3: risk of bias assessment.

\section{Discussion}

This review was aimed at identifying factors associated with antiretroviral treatment failure among individuals living with HIV and showed that low CD4 T cell count $\left(\leq 200\right.$ cells $\left./ \mathrm{mm}^{3}\right)$ and poor adherence to ART were significantly associated with virological failure.

In this review, the odds of virological failure were higher among those who had a CD4 cell count of $\leq$

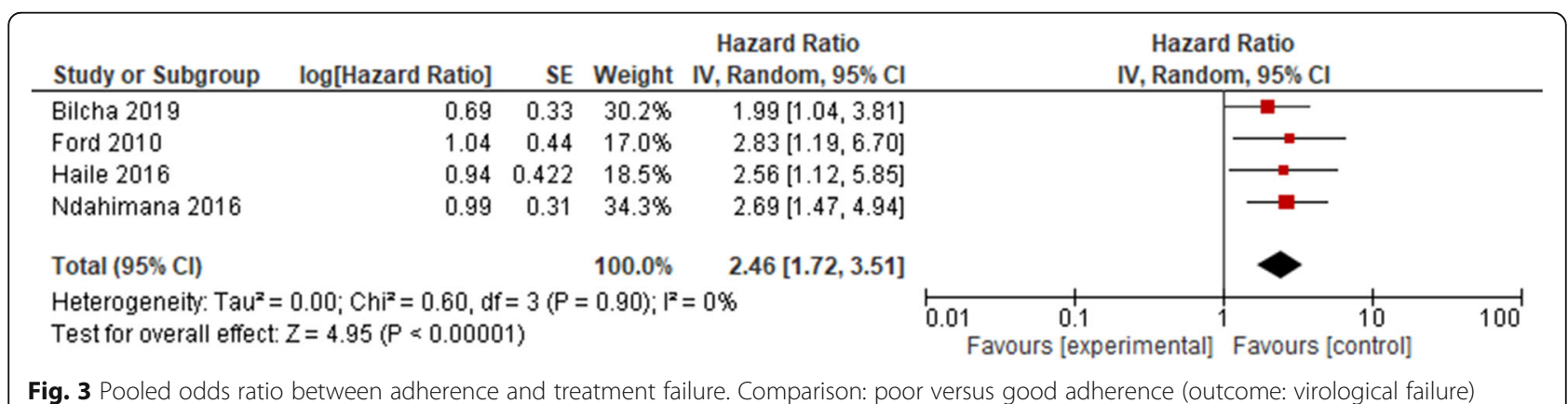




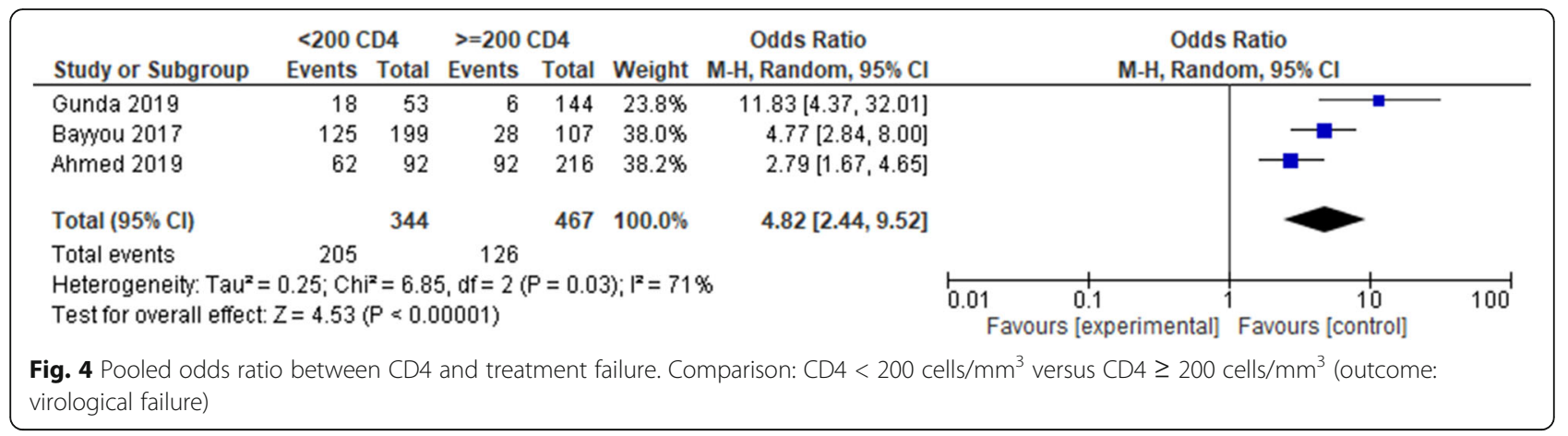

200cells $/ \mathrm{mm}^{3}$ in both case-control and cohort studies. The finding is supported by the studies conducted in SSA [35, 43], while a retrospective analysis of a large ART program in Cambodia showed that previous ART experience, nevirapine-based regimen, and CD4 count $\leq$ 200 cells $/ \mathrm{mm}^{3}$ were independently associated with an increased risk of treatment [48]. Similar findings were reported in a meta-analysis data from India, where CD4 count $\leq 200$ had a significantly greater risk of treatment failure [49]. As CD4 cell count increases, viral replication decreases, which means it has an inverse relationship with viral load. As patients' immune status drops, and the rate of viral load increases compared to the immuno-competent individuals with HIV infection. In addition, users with compromised immunity are more susceptible to different opportunistic infections that endure the cruel cycle of immunity depletion and viral replication [50].

Moreover, the results found from case-control studies shown that the odds of virological failure were 6 times more among those who had poor adherence compared with those who had good adherence to antiretroviral treatment. Likewise, the finding from cohort studies showed that the odds of virological failure were higher among those who had poor adherence compared with those who had good adherence to antiretroviral treatment. This finding is supported by findings from primary studies conducted in African countries [11, 51, 52], but also consistent with the finding from a study conducted in Vietnam and other developed countries [53-
55]. It is obvious that poor adherence to medication compromises treatment response due to suboptimal drug concentration hence creates a conducive environment for viral replication leading to virological failure $[56,57]$. This reaffirms the need for reinforcement of drug adherence counseling for HIV patients before and during their life course of taking ART.

Poor adherence may lead to a number of adverse consequences on both individual and public HIV healthcare levels. Therefore, the measured efforts are immediately needed in HIV care by responsive bodies like ART case managers, adherence counselors in the hospitals on patients with low current CD4 count through improving poor adherence to ART treatment by strengthening enhanced adherence counseling. Each low-income country national HIV program should give attention to improving HIV services to strengthen adherence among patients on ART in order to reduce the proportion of patients who are failing the treatment.

Our systematic review has some strengths. We planned the review a priori with clearly defined selection criteria. We conducted a comprehensive and exhaustive search, using many additional sources to identify relevant studies, including reference searches of other HIV/ AIDS conferences (IAS and CROI) for the past 20 years.

This review had several limitations mainly related to the quality of the evidence available. To our knowledge, we suspect publication or reporting biases, or both, suggesting that our results may be overestimated. Positive study bias is likely to be problematic in this review. Our

\begin{tabular}{|c|c|c|c|c|c|c|c|}
\hline Study or Subgroup & $\log [$ Hazard Ratio] & SE & Weight & $\begin{array}{c}\text { Hazard Ratio } \\
\text { IV, Random, } 95 \% \mathrm{Cl}\end{array}$ & $\begin{array}{r}\text { Hazard } \\
\text { IV, Randon }\end{array}$ & $\begin{array}{l}\text { d Ratio } \\
\mathrm{m}, 95 \% \mathrm{Cl}\end{array}$ & \\
\hline Bilcha 2019 & 0.69 & 0.32 & $21.9 \%$ & $1.99[1.06,3.73]$ & & $\longrightarrow$ & \\
\hline Fatti 2019 & 1.25 & 0.29 & $26.6 \%$ & $3.49[1.98,6.16]$ & & $\longrightarrow$ & \\
\hline Lay 2017 & 1.15 & 0.29 & $26.6 \%$ & $3.16[1.79,5.58]$ & & $\rightarrow-$ & \\
\hline Ndahimana 2016 & 1.22 & 0.3 & $24.9 \%$ & $3.39[1.88,6.10]$ & & $\longrightarrow$ & \\
\hline Total $(95 \% \mathrm{Cl})$ & & & $100.0 \%$ & $2.98[2.23,4.00]$ & & & \\
\hline \multicolumn{5}{|c|}{$\begin{array}{l}\text { Heterogeneity: } \text { Tau }^{2}=0.00 ; \mathrm{Chi}^{2}=2.10, \mathrm{df}=3(P=0.55) ;\left.\right|^{2}=0 \% \\
\text { Test for overall effect: } Z=7.31(P<0.00001)\end{array}$} & $\begin{array}{ccc}0.01 & 0.1 \\
& \text { Favours [experimental] }\end{array}$ & $\begin{array}{c}10 \\
\text { Favours [control] }\end{array}$ & 100 \\
\hline
\end{tabular}




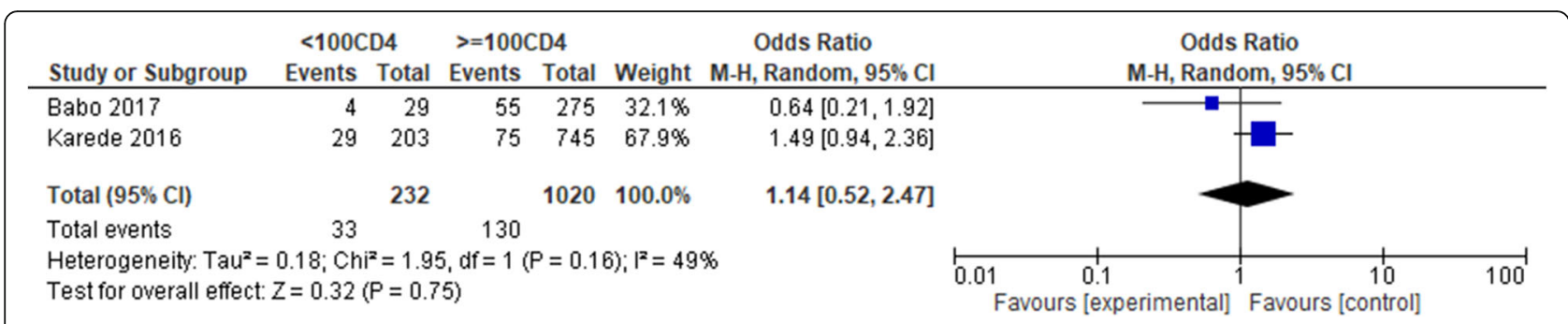

Fig. 6 Pooled odds ratio between CD4 and treatment failure. Comparison: CD4 < 100 versus CD4 $\geq 100$. (outcome: virological failure)

literature search for relevant and potential studies included focused searches, i.e., including search terms related to the "less CD4 count," "viral load" in our electronic search. Studies that report a relationship between the prognostic factors and common outcomes are therefore more likely to have been identified in these searches due to reporting of positive results in the study abstract.

In addition, we also observed that some studies reported positive unadjusted association of factors with outcomes of interest, but did not report the association adjusted for other important covariates. This may contribute to a likely overestimation of the adjusted results. Therefore, future research is required to investigate the impact and potential strategies to alleviate reporting and publication bias, as well as initiatives to require registration of protocols and publication of prognostic studies.

Furthermore, our review was the pooling of the adjusted the results despite studies did not include identical sets of covariates. Studies included in this review were homogenous; therefore, pooling of the adjusted results was feasible. However, comparison and interpretation may be challenging in this case. Our review only focused on studies conducted in poor resource settings limiting its generalizability to high-income settings.

\section{Strength of evidence}

The strength of evidence contributing to several outcomes in this review was graded as low, moderate, or high. We used the GRADE approach to assess the strength of evidence as shown in the summary of the finding table, Appendix 4. The certainty of evidence was downgraded in most instances due to a high risk of bias as well as inconsistency.

\section{Conclusion}

ART failure among individuals living with HIV is a public health concern; the timing and accuracy of identifying treatment failure in resource-limited settings are fundamental but challenging. The findings of this review highlighted that low CD4 counts and poor adherence to ART were associated to ART treatment failure. There is an urgent need that health professionals and HIV programs should focus on novel approaches for patients who have these characteristics in order to prevent ART failure. Further review is required to be done in multiple ART centers and a broader community as well as the different factors associated with treatment failure to decide whether there are discrepancies in virological and immunological responses to antiretroviral therapy at different stages of HIV infection.

\section{Appendix 1}

\section{Search strategy-database}

\#1 Search ((HIV OR hiv-1 OR hiv-2* OR hiv1 OR hiv2 OR hiv infect* OR human immunodeficiency virus OR human immune deficiency virus OR human immunodeficiency virus OR human immune-deficiency virus OR ((human immun*) AND (deficiency virus)) OR acquired immune deficiency syndromes

OR acquired immune deficiency syndrome OR acquired immuno-deficiency syndrome OR

acquired immune-deficiency syndrome OR ((acquired immun") AND (deficiency syndrome)) OR HIV/AIDS))

\#2 Search ((HIV infections [MeSH] OR HIV [MeSH])) \#3 Search (\#1 OR \#2)

\#4 Search ((Antiretroviral* OR ((anti) AND (retroviral*)) OR ARV* OR ART OR "antiretroviral therapy"

OR HAART OR ((highly) AND (active) AND (antiretroviral*) AND (therap*)) OR ((anti) AND (hiv)) OR

((anti) AND (acquired immunodeficiency)) OR ((anti) AND (acquired immuno-deficiency)) OR ((anti)

AND (acquired immune-deficiency)) OR ((anti) AND (acquired immun*) AND (deficienc*))))

\#5 Search ((antiretroviral agents [Mesh] OR antiretroviral therapy, highly active [Mesh]))

\#6 Search (\#4 OR \#5)

\#7 search \#3 AND \#6

\#8 Search (virological failure OR Immunological failure OR less CD4 count OR viral load)

\#9 Search (low-income setting OR disadvantaged communities OR resource limited setting OR Sub-Saharan Africa)

\#10 Search (\#7 AND \#8 AND \#9) 


\section{Appendix 3}

\section{Risk of bias assessment}

Table 2 Risk of bias assessment

\begin{tabular}{|c|c|c|c|c|c|c|c|}
\hline \multirow[t]{2}{*}{$\#$} & \multirow[t]{2}{*}{ Study ID } & \multicolumn{2}{|l|}{ Study } & \multicolumn{3}{|l|}{ Prognostic } & \multirow{2}{*}{$\begin{array}{l}\text { Statistical } \\
\text { analysis } \\
\text { and } \\
\text { reporting }\end{array}$} \\
\hline & & participant & Attrition & Factor measurement & Outcome measurement & Study confounding & \\
\hline 1 & Abah 2018 & Low & High & Low & Low & Low & Low \\
\hline 2 & Ahmed 2019 & Low & Low & Low & Low & Low & Low \\
\hline 3 & Ahn 2019 & Low & High & Low & Low & Low & Low \\
\hline 4 & Ahoua 2009 & Low & Low & Low & Low & Low & Low \\
\hline 5 & Assefa 2014 & Low & High & Low & Low & Low & Low \\
\hline 6 & Ayalew 2016 & Low & Low & Low & Low & Low & Low \\
\hline 7 & Ayele 2018 & Low & Low & Low & Low & Low & Low \\
\hline 8 & Babo 2017 & Low & Low & Low & Low & Low & Low \\
\hline 9 & Bayou 2015 & Low & High & Low & Low & Low & Low \\
\hline 10 & Bayu 2017 & Low & Low & Low & Low & Low & Low \\
\hline 11 & Billioux 2015 & Low & Low & High & High & Low & Low \\
\hline 12 & Biscione 2014 & Low & Low & High & High & High & Low \\
\hline 13 & Bisson 2008 & Low & Low & High & Low & High & Low \\
\hline 14 & Boender 2016a & Low & Low & Low & Low & Low & Low \\
\hline 15 & Boender 2016b & Low & Low & Low & Low & Low & Low \\
\hline 16 & Boettiger 2016c & Low & Low & Low & Low & Low & Low \\
\hline 17 & Boettiger 2015 & Low & Low & Low & Low & Low & Low \\
\hline 18 & Boettiger 2016d & Low & Low & Low & Low & Low & Low \\
\hline 19 & Boettiger 2014 & Low & Low & Low & Low & Low & Low \\
\hline 20 & Boulle 2015 & Low & Low & Low & Low & Low & Low \\
\hline 21 & Braun 2017 & Low & Low & Low & Low & High & High \\
\hline 22 & Brooks 2016 & Low & Low & Low & Low & High & High \\
\hline 23 & Bulage 2017 & Low & High & Low & Low & Low & Low \\
\hline 24 & Byabene 2017 & Low & Low & Low & Low & Low & Low \\
\hline 25 & Cao 2018 & Low & Low & Low & Low & Low & Low \\
\hline 26 & Carriquiry 201 & Low & Low & Low & Low & Low & Low \\
\hline 27 & Caseiro 2018 & Low & Low & Low & High & High & Low \\
\hline 28 & Castelnuovo 2016 & Low & Low & Low & Low & Low & Low \\
\hline 29 & Cesar 2015 & Low & Low & Low & Low & Low & Low \\
\hline 30 & Cesar 2014 & Low & Low & Low & Low & Low & Low \\
\hline 31 & Chaiwarith 2011 & Low & Low & Low & Low & Low & Low \\
\hline 32 & Chaiwarith 2007 & Low & Low & High & Low & Unclear & Low \\
\hline 33 & Chakravarty 2015 & Low & Low & Low & Low & Unclear & Low \\
\hline 34 & Charles 2013 & Low & Unclear & Low & Low & Unclear & Low \\
\hline 35 & Chawana 2014 & Low & Low & Low & Low & Unclear & Low \\
\hline 36 & Chen 2014 & Low & High & Low & Low & High & Low \\
\hline 37 & Chhim 2018 & Low & High & Low & Low & Low & Low \\
\hline 38 & Chkhartishvili 2014 & Low & Low & Low & Low & Unclear & Low \\
\hline 39 & Collier 2017 & Low & Low & Low & Low & Low & Low \\
\hline 40 & Costiniuk 2014 & High & Unclear & Low & Low & High & High \\
\hline
\end{tabular}


Table 2 Risk of bias assessment (Continued)

\begin{tabular}{|c|c|c|c|c|c|c|c|}
\hline \multirow[t]{2}{*}{ \# } & \multirow[t]{2}{*}{ Study ID } & \multicolumn{2}{|l|}{ Study } & \multicolumn{3}{|l|}{ Prognostic } & \multirow{2}{*}{$\begin{array}{l}\text { Statistical } \\
\text { analysis } \\
\text { and } \\
\text { reporting }\end{array}$} \\
\hline & & participant & Attrition & Factor measurement & Outcome measurement & Study confounding & \\
\hline 41 & Court 2014 & Low & Low & Low & Low & Low & Low \\
\hline 42 & Datay 2010 & Low & Low & Low & Low & Unclear & Low \\
\hline 43 & DeBoni 2018 & Low & Low & Low & Low & Low & Low \\
\hline 44 & deLaHoz 2014 & Low & Low & Unclear & Unclear & Unclear & Low \\
\hline 45 & Dolling 2017 & Low & Low & Low & Low & Low & Low \\
\hline 46 & Dray-Spira 2007 & Low & Low & Low & Low & Unclear & Low \\
\hline 47 & Ekstrand 2011 & Low & Low & High & Unclear & Unclear & High \\
\hline 48 & Rusine 2013 & Low & Low & Low & Low & Low & Low \\
\hline 49 & Sadashiv 2017 & Low & Low & Low & Low & Low & Low \\
\hline 50 & Safren 2014 & Low & Low & Low & Low & Low & Low \\
\hline 51 & Saracino 2014 & Low & Low & Low & Low & Low & Low \\
\hline 52 & Singini 2016 & Low & Low & Low & Low & Low & Low \\
\hline 53 & Sithole 2018 & Low & Low & Low & Low & Low & Low \\
\hline 54 & Sovershaeva 2019 & Low & Low & Low & Low & Low & Low \\
\hline 55 & Syed 2016 & Low & Low & Low & Low & Low & Low \\
\hline 56 & Telele 2018 & Low & Low & Low & Low & Low & Low \\
\hline 57 & Teshome 2014 & Low & Low & Low & Low & Low & Low \\
\hline 58 & Thiha 2016 & High & Low & Low & Low & Low & Low \\
\hline 59 & Tran 2014 & Low & High & Low & Low & Low & Low \\
\hline 60 & Tsegaye 2016 & Low & High & Low & Low & Low & Low \\
\hline 61 & vandenBerg 2005 & Low & Low & Low & Low & Low & Low \\
\hline 62 & Vanobberghen 2015 & Low & Low & Low & Low & Low & Low \\
\hline 63 & Wang 2011 & High & High & Low & Low & Low & Low \\
\hline 64 & Yimer 2015 & Low & Low & Low & Low & Low & Low \\
\hline 65 & Yirdaw 2015 & Low & Low & Low & Low & Low & Low \\
\hline 66 & Zhao 2017 & Low & High & Low & Low & Low & Low \\
\hline 67 & Zoufaly 2015 & Low & Low & Low & Low & Low & Low \\
\hline 68 & Elema 2009 & Low & Low & Unclear & low & Unclear & Low \\
\hline 69 & Enderis 2009 & Low & Low & Low & Low & Low & Low \\
\hline 70 & Eshleman 2017 & Low & Low & Low & Low & Low & Low \\
\hline 71 & Evans 2018 & Low & High & Low & Low & Low & Low \\
\hline 72 & Evans 2013 & Low & High & Low & Low & Low & Low \\
\hline 73 & Fatti 2019 & Low & Low & Low & Low & Low & Low \\
\hline 74 & Fatti 2014 & Low & Low & Low & Low & Low & Low \\
\hline 75 & Ferradini 2007 & Low & Low & Low & Low & Low & Low \\
\hline 76 & Ferreyra 2012 & Low & Low & Low & Low & Low & Low \\
\hline 77 & Fibriani 2013 & Low & Low & Low & Unclear & Unclear & Low \\
\hline 78 & Flynn 2017 & Low & Low & Low & Low & Low & Low \\
\hline 79 & Fogel 2017 & unclear & Unclear & Low & Low & Low & Unclear \\
\hline 80 & Ford 2010 & Low & Low & Low & Low & Low & Low \\
\hline 81 & Fox 2012 & Low & Low & Low & Low & Low & Low \\
\hline 82 & Fox 2010 & Low & Low & Low & Low & Low & Low \\
\hline
\end{tabular}


Table 2 Risk of bias assessment (Continued)

\begin{tabular}{|c|c|c|c|c|c|c|c|}
\hline \multirow{2}{*}{ \# } & \multirow[t]{2}{*}{ Study ID } & \multicolumn{2}{|l|}{ Study } & \multicolumn{3}{|l|}{ Prognostic } & \multirow{2}{*}{$\begin{array}{l}\text { Statistical } \\
\text { analysis } \\
\text { and } \\
\text { reporting }\end{array}$} \\
\hline & & participant & Attrition & Factor measurement & Outcome measurement & Study confounding & \\
\hline 83 & Goldman 2008 & Low & Low & Low & Low & Unclear & Low \\
\hline 84 & Gross 2017 & Low & Low & Low & Low & Low & Low \\
\hline 85 & Gunda 2019 & Low & Low & Low & Low & Low & Low \\
\hline 86 & Haggblom 2016 & Low & Low & Low & Low & Low & Low \\
\hline 87 & Haile 2016 & Low & High & Low & Low & High & Low \\
\hline 88 & Hailu 2018 & Low & Low & Low & Low & Low & Low \\
\hline 89 & Hamers 2012 & Low & Low & Low & Low & Low & Low \\
\hline 90 & Hare 2014 & Low & Low & Low & Low & Low & Low \\
\hline 91 & Hassan 2014 & Low & Low & Low & Low & Low & Low \\
\hline 92 & Hawkins 2015 & Low & High & Low & Low & Low & Low \\
\hline 93 & Hawkins 2016 & Low & Low & Low & Low & Low & Low \\
\hline 94 & Hermans 2018 & Low & High & Unclear & Low & Unclear & Low \\
\hline 95 & Huang 2015 & Low & High & Low & Low & Low & Low \\
\hline 96 & Hunt 2017 & Low & Low & Low & High & Unclear & Low \\
\hline 97 & Huong 2011 & Low & Low & Low & low & Unclear & Low \\
\hline 98 & Inzaule 2018 & Low & Low & Unclear & low & Low & Low \\
\hline 99 & Izudi 2016 & Low & Low & Unclear & low & Low & Low \\
\hline 100 & Jiamsakul 2016 & Low & High & Low & low & Low & Low \\
\hline 101 & John 2016 & Low & Low & Low & low & Low & Low \\
\hline 102 & Joram 2017 & Low & High & Low & High & Low & Low \\
\hline 103 & JosephDavey 2018 & Low & Low & Low & low & Low & Low \\
\hline 104 & Kamya 2007 & Low & Low & Unclear & low & Low & Low \\
\hline 105 & Kan 2017 & Low & Low & Low & High & Low & Low \\
\hline 106 & Karade 2016 & Low & Low & Low & High & Low & Low \\
\hline 107 & Kazooba 2018 & Low & High & Low & Low & Low & Low \\
\hline 108 & Khienprasit 2011 & Low & Low & Low & High & Low & High \\
\hline 109 & Kyaw 2017 & Low & High & Low & High & Low & Low \\
\hline 110 & Lay 2017 & Low & Low & Low & High & Low & High \\
\hline 111 & Leng 2014 & Low & Low & High & High & Low & Low \\
\hline 112 & Lenjisa 2015 & Low & High & Low & Low & Low & High \\
\hline 113 & Levison 2011 & Low & Low & Low & Low & High & High \\
\hline 114 & Liegeois 2013 & Low & Low & Low & High & Low & High \\
\hline 115 & Masikini 2019 & High & Low & Low & High & Low & Low \\
\hline 116 & Meloni 2016 & Low & Low & Low & High & High & Low \\
\hline 117 & Mpawa 2017 & High & High & Low & High & Low & High \\
\hline 118 & Mujugira 2016 & Low & Low & Low & low & Low & Low \\
\hline 119 & Mungwira 2018 & Low & High & Low & High & Low & Low \\
\hline 120 & Musa 2015 & Low & Low & Low & Low & Low & Low \\
\hline 121 & Nachega 2008 & High & Low & Low & Low & High & Low \\
\hline 122 & Ndahimana 2016 & High & Low & Low & Low & Low & High \\
\hline 123 & Negi 2018 & Low & High & Low & Low & Low & Hlgh \\
\hline 124 & Nsanzimana 2019 & High & High & Low & Low & Low & High \\
\hline
\end{tabular}


Table 2 Risk of bias assessment (Continued)

\begin{tabular}{|c|c|c|c|c|c|c|c|}
\hline \multirow[t]{2}{*}{$\#$} & \multirow[t]{2}{*}{ Study ID } & \multicolumn{2}{|l|}{ Study } & \multicolumn{3}{|l|}{ Prognostic } & \multirow{2}{*}{$\begin{array}{l}\text { Statistical } \\
\text { analysis } \\
\text { and } \\
\text { reporting }\end{array}$} \\
\hline & & participant & Attrition & Factor measurement & Outcome measurement & Study confounding & \\
\hline 125 & Ntamatungiro 2017 & Low & High & Low & Low & Low & High \\
\hline 126 & Ongubo 2017 & High & High & Low & Low & Low & High \\
\hline 127 & Onoya 2016 & Low & High & Low & Low & Low & Low \\
\hline 128 & Palladino 2013 & High & Low & Low & Low & Low & Low \\
\hline 129 & Patrikar 2017 & Low & Low & Low & High & Low & High \\
\hline 130 & Penot 2014 & High & Low & Low & High & Low & High \\
\hline 131 & Raimondo 2017 & Low & Low & Low & low & Low & Low \\
\hline 132 & Rajasekaran 2007 & Low & Low & Low & High & High & Low \\
\hline 133 & Ramadhani 2007 & High & Low & Low & low & Low & High \\
\hline 134 & Rangarajan 2016 & Low & High & Low & low & Low & Low \\
\hline 135 & Rohr 2016 & Low & High & Low & low & Unclear & Low \\
\hline 136 & Ruperez 2014 & High & Low & Low & low & Low & High \\
\hline 137 & Ruperez 2015 & High & Low & Low & low & Low & High \\
\hline
\end{tabular}

\section{Appendix 2}

\section{Risk of bias criteria and justifications}

\begin{tabular}{|c|c|c|}
\hline \multicolumn{3}{|c|}{ Assessment for risk of bias } \\
\hline First author & \multicolumn{2}{|c|}{ Reviewer.............................. } \\
\hline Biases & $\begin{array}{l}\text { Issues to } \\
\text { consider } \\
\text { for judging } \\
\text { overall } \\
\text { rating of } \\
\text { "risk of } \\
\text { bias" }\end{array}$ & $\begin{array}{l}\text { Study } \\
\text { methods } \\
\text { and } \\
\text { comments }\end{array}$ \\
\hline $\begin{array}{l}\text { Assess the risk } \\
\text { of each } \\
\text { potential bias }\end{array}$ & $\begin{array}{l}\text { These issues } \\
\text { will guide } \\
\text { your } \\
\text { thinking and } \\
\text { judgment } \\
\text { about the } \\
\text { overall risk } \\
\text { of bias } \\
\text { within each } \\
\text { of the } 6 \\
\text { domains. }\end{array}$ & $\begin{array}{l}\text { Provide } \\
\text { comments } \\
\text { or excerpts } \\
\text { to facilitate } \\
\text { the } \\
\text { consensus } \\
\text { process that } \\
\text { will follow }\end{array}$ \\
\hline $\begin{array}{l}\text { 1) Study } \\
\text { participation }\end{array}$ & \multicolumn{2}{|c|}{$\begin{array}{l}\text { The study sample } \\
\text { adequately represents the } \\
\text { population of interest }\end{array}$} \\
\hline \multicolumn{3}{|c|}{$\begin{array}{l}\text { a. Adequate participation in } \\
\text { the study by eligible persons } \\
(>80 \%)\end{array}$} \\
\hline \multicolumn{3}{|c|}{$\begin{array}{l}\text { b. Description of the source } \\
\text { population or population of } \\
\text { interest }\end{array}$} \\
\hline \multicolumn{3}{|c|}{$\begin{array}{l}\text { c. Description of the baseline } \\
\text { study sample }\end{array}$} \\
\hline \multicolumn{3}{|c|}{$\begin{array}{l}\text { d. Adequate description of } \\
\text { the sampling frame and } \\
\text { recruitment. }\end{array}$} \\
\hline
\end{tabular}

\section{Risk of bias criteria and justifications (Continued)}

e. Adequate description of the period and place of recruitment

f. Adequate description of inclusion and exclusion criteria

2) Study The study data available (i.e., participants not lost to follow-up) adequately represent the study sample

High, moderate, low

Summary

High bias: The relationship between the PF and outcome is very likely to be different for participants and eligible nonparticipantsModerate bias:The relationship between the PF and outcome may be different for participants and eligible nonparticipantsLow bias: The relationship between

\section{3) Prognostic The PF is measured in a factor similar way for all measurement participants}

a. A clear definition or description of the PF is provided

b. Method of PF

measurement is adequately valid and reliable (i.e., direct

the PF and outcome is unlikely to be different for participants and eligible nonparticipants

Summary

High bias: The relationship between the $\mathrm{PF}$ and outcome is very likely to be different for completing and noncompeting participantsModerate bias: The relationship between the PF and outcome may be different for completing and noncompeting participantsLow bias: The relationship between the

$\mathrm{PF}$ and outcome is unlikely to be different for completing and noncompeting participants

Summary

High bias: The measurement of the PF is very likely to be different for different levels of the outcome of interestModerate bias: 


\section{Risk of bias criteria and justifications (Continued)}

ascertainment; secure record, hospital record)

c. Continuous variables are reported or appropriate cutpoints are used

d. The method and setting of measurement of PF is the same for all study

participants

e. Adequate proportion of the study sample has complete data for the PF (> 80\%)

f. Appropriate methods of imputation are used for missing PF data

4) Outcome The outcome of interest is measurement measured in a similar way for all participants

a. A clear definition of the outcome of interest is provided (including the time of death)

b. Method of outcome measurement used is adequately valid and reliable (i.e. independent blind assessment, hospital record or record linkage)

c. The method and setting of outcome measurement is the same for all study participants

\section{5) Study Important potential \\ confounding confounder is appropriately accounted for}

\section{a. Most important} confounders are measured

b. Clear definitions of the important confounders measured are provided

\section{c. Measurement of all} important confounders is adequately valid and reliable

d. The method and setting of confounding measurement are the same for all study participants

e. Appropriate methods are used if imputation is used for missing confounder data

f. Important potential confounders are accounted for in the study design (by limiting the study to specific population groups, or by matching)

g. Important potential confounders are accounted for in the analysis (by
The measurement of the PF may be different for different levels of the outcome of interestLow bias: The measurement of the PF is unlikely to be different for different levels of the outcome of interest

Summary

High bias: The

measurement of the outcome is very likely to be differently related to the baseline level of the PFModerate bias: The measurement of the outcome may be differently related to the baseline level of the

PFLow bias: The measurement of the outcome is unlikely to be differently related to the baseline level of the PF

\section{Summary}

High bias: The observed effect of the PF on the outcome is very likely to be distorted by another factor related to PF and outcomeModerate bias: The observed effect of the PF on outcome may be distorted by another factor related to PF and outcomeLow bias: The observed effect of the PF on the outcome is unlikely to be distorted by another factor related to PF and outcome
Risk of bias criteria and justifications (Continued)

stratification, multivariate regression)

6) Statistical The statistical analysis is analysis and appropriate, and all primary presentation outcomes are reported

a. Sufficient presentation of data to assess the adequacy of the analytic strategy

b. Strategy for model building is appropriate and is based on a conceptual framework or model

c. The selected statistical model is adequate for the design of the study

d. There is no selective reporting of results (based on the study protocol, if available, or on the "Methods" section)

\section{Summary} results are very likely to be spurious or biased related to analysis or reportingModerate bias: The reported results may be spurious or biased related to analysis or reportingLow bias: The reported results are unlikely to be spurious or biased related to analysis or reporting 


\section{Appendix 4}

\section{Strength of evidence}

Table 3 Summary of findings of included studies using the GRADE methodology (Grading of Recommendations Assessment, Development and Evaluation)

\begin{tabular}{|c|c|c|c|}
\hline Factors assessed & $\begin{array}{l}\text { Number of studies } \\
\text { (SD) }\end{array}$ & Main findings & $\begin{array}{l}\text { Strength of evidence (high, moderate, low, } \\
\text { very low) }\end{array}$ \\
\hline Adherence (poor versus good) & 6 (cross-sectional) & $\begin{array}{l}\text { Odds ratio: } 5.90 \text { (95\%Cl, 3.50- } \\
\text { 9.94) }\end{array}$ & Moderate $^{a}$ \\
\hline Adherence (poor versus good) & 4 (cohort studies) & $\begin{array}{l}\text { Hazar ratio: } 2.46(95 \% \mathrm{Cl}, 1.72- \\
3.51)\end{array}$ & High \\
\hline $\begin{array}{l}\text { CD4 cell count }(<200 \text { versus } \geq 200 \\
\left.\text { cells } / \mathrm{mm}^{3}\right)\end{array}$ & 3 (cross-sectional) & $\begin{array}{l}\text { Odd ratio: } 4.82 \text { (95\% Cl, 2.44- } \\
9.52)\end{array}$ & Low $^{b}$ \\
\hline $\begin{array}{l}\text { CD } 4 \text { cell count }(<200 \text { versus } \geq 200 \\
\left.\text { cells } / \mathrm{mm}^{3}\right)\end{array}$ & 4 (cohort studies) & $\begin{array}{l}\text { Hazard ratio: } 2.98(95 \% \mathrm{Cl}, \\
2.23-4.0)\end{array}$ & Moderate $^{c}$ \\
\hline $\begin{array}{l}\text { CD4 cell count }(<100 \text { versus } \geq 100 \\
\left.\text { cells } / \mathrm{mm}^{3}\right)\end{array}$ & 2 (cross-sectional) & $\begin{array}{l}\text { Odds ratio: } 1.14(95 \% \mathrm{Cl}, 0.52- \\
2.47)\end{array}$ & Low $^{d}$ \\
\hline
\end{tabular}

\section{SD study design}

${ }^{a}$ Downgraded once to indirectness, the final sample of some of the included studies only represents the population of interest

${ }^{\mathrm{b}}$ Imprecision and inconsistency were major concerns, imprecision due to a limited number of studies and wide confidence intervals, and there was a substantial heterogeneity statistical heterogeneity (heterogeneity: $\mathrm{Tau}^{2}=0.25 ; \mathrm{chi}^{2}=6.25, \mathrm{df}=2(P=0.03), I^{2}=71 \%$ ) and marked clinical heterogeneity

'Downgraded once due to a risk of bias, bias to statistical analysis and reporting, and potential confounding factors

${ }^{\mathrm{d}}$ Imprecision due to a limited number of participants and studies included. Inconsistency as there was a moderate statistical heterogeneity (heterogeneity: Tau ${ }^{2}=$ $\left.0.18 ; \mathrm{Chi}^{2}=1.95, \mathrm{df}=1(P=0.16) ; l^{2}=49 \%\right)$

GRADE Working Group grades of evidence

High certainty: We are very confident that the true effect lies close to that of the estimate of the effect

Moderate certainty: We are moderately confident in the effect estimate: The true effect is likely to be close to the estimate of the effect, but there is a possibility that it is substantially different

Low certainty: Our confidence in the effect estimate is limited: The true effect may be substantially different from the estimate of the effect

\section{Abbreviations}

AIDS: Acquired immune deficiency syndrome; ART: Antiretroviral therapy; BMI: Body mass index; CDC: Centers for Disease Control and Prevention; CENTRAL: Cochrane Central Register of Controlled Trials; EMBASE: Excerpta Medica Database; HRs: Hazard ratios; HIV: Human immunodeficiency virus; IRIS: Immune reconstitution inflammatory syndrome; LILACS: Latin American and Caribbean Health Sciences Literature; LMICs: Low- and middle-income countries; MEDLINE: Medical Literature Analysis and Retrieval System Online NNRTI: Non-nucleotide reverse transcriptase inhibitors; NRTI: Nucleotide reverse transcriptase inhibitors; OR: Odds ratio; PLHIV: People living with human immunodeficiency virus; PRISMA-P: Preferred Reporting Items for Systematic Reviews and Meta-Analysis Protocols; PROSPERO: Prospective Register of Systematic Reviews; PubMed: Public/Publisher MEDLINE; RRs: Risk ratios; SSA: Sub-Saharan Africa; TB: Tuberculosis; UNAIDS: United Nations Programme on HIV; WHO: World Health Organization

\section{Acknowledgements}

Not applicable.

\section{Authors' contributions}

$\mathrm{YL}, \mathrm{MK}$, and PN contributed to the conceptualization of the project. $\mathrm{YL}, \mathrm{MK}$, SJ, OA, and PN designed the search strategy, study selection process, and drafting of the manuscript. YL, MK, SJ, OA, and PN contributed to critically reviewing the manuscript. PN is the guarantor. The authors gave the final approval of the manuscript for publication.

\section{Funding}

No funding was received for this systematic review.

\section{Availability of data and materials}

All data generated or analyzed during this study are included in this published article and its additional files.

Ethics approval and consent to participate

Not applicable because no primary data were collected.
Consent for publication

Not applicable

Competing interests

The authors declare that they have no competing interests.

\section{Author details}

${ }^{1}$ Division of Epidemiology and Biostatistics, Department of Global Health, Faculty of Medicine and Health Sciences, Stellenbosch University, Cape Town, South Africa. ${ }^{2}$ Médecins Sans Frontières (MSF), Eshowe, KwaZulu Natal, South Africa. ${ }^{3}$ Division of Epidemiology \& Biostatistics, School of Public Health, Faculty of Health Sciences, University of the Witwatersrand, Johannesburg, South Africa.

Received: 5 May 2020 Accepted: 8 November 2020

Published online: 12 December 2020

\section{References}

1. UNAIDS. UNAIDS Report on the Global AIDS Epidemic 2019; 2018. p. 1-376.

2. Renaud-théry AF, Duncombe C, Kerr S, Thierry S. Adult antiretroviral therapy in resource limited settings : a systematic review of first-line failure and attrition rates. WHO Tech $\mathrm{Br}$. :1-18.

3. Boyd MA. Current and future management of treatment failure in low- and middle-income countries. Curr Opin HIV AIDS. 2010;5(1):83-9.

4. Joint United Nations Programme on HIV/AIDS (UNAIDS). Ambitious treatment targets: writing the final chapter of the AIDS epidemic. Geneva:

5. Joint United Nations Programme on HIV/AIDS. Global AIDS update 2016. Geneva: UNAIDS.

6. El-Khatib Z, Katzenstein D, Marrone G, Laher F, Mohapi L, Petzold M, Morris $L$, Ekström AM. Adherence to drug-refill is a useful early warning indicator of virologic and immunologic failure among HIV patients on first-line ART in South Africa. PloS one. 2011;6(3):e17518. https://doi.org/10.1371/journal. pone.0017518.

7. Vanobberghen FM, Kilama B, Wringe A, Ramadhani A, Zaba B, Mmbando D, Todd J. Immunological failure of first-line and switch to second-line antiretroviral therapy among HIV-infected persons in Tanzania: analysis of routinely collected national data. Tropical Med Int Health. 2015;20(7):880-92. 
8. Ncaca LN, Kranzer K, Orrell C. Treatment interruption and variation in tablet taking behaviour result in viral failure: a case-control study from Cape Town, South Africa. PloS One. 2011;6(8):e23088. https://doi.org/10.1371/journal. pone.0023088

9. Yayehirad AM, Mamo WT, Gizachew AT, Tadesse AA. Rate of immunological failure and its predictors among patients on highly active antiretroviral therapy at Debremarkos Hospital, Northwest Ethiopia: a retrospective follow up study. J AIDS Clin Res. 2013;4(5). https://doi.org/10.4172/2155-6113. 1000211.

10. World Health Organisation. Consolidated guidelines on the use of antiretroviral drugs for treating and preventing HIV infection: recommendations for a public health approach. WHO Guidelines. 2013; 272.

11. Bulage L, Ssewanyana I, Nankabirwa V, Nsubuga F, Kihembo C, Pande G, Ario AR, Matovu JK, Wanyenze RK, Kiyaga C. Factors associated with virological non-suppression among HIV-positive patients on antiretroviral therapy in Uganda, August 2014-July 2015. J BioMed Central Infectious Dis. 2017;17(1):326

12. Palladino C, Briz V, Bellón JM, Bartolo I, Carvalho P, Camacho R, et al. Predictors of attrition and immunological failure in HIV-1 patients on highly active antiretroviral therapy from different healthcare settings in Mozambique. PLoS One. 2013;8(12):e82718. https://doi.org/10.1371/journal. pone.0082718

13. Anude CJ, Eze E, Onyegbutulem HC, Charurat M, Etiebet MA, Ajayi S, Dakum P, Akinwande $\mathrm{O}$, Beyrer C, Abimiku AL, Blattner W. Immuno-virologic outcomes and immuno-virologic discordance among adults alive and on anti-retroviral therapy at 12 months in Nigeria. BioMed Central Infectious Dis. 2013;13(1):113.

14. Hassan AS, Nabwera HM, Mwaringa SM, Obonyo CA, Sanders EJ, de Wit TF, Cane PA, Berkley JA. HIV-1 virologic failure and acquired drug resistance among first-line antiretroviral experienced adults at a rural HIV clinic in coastal Kenya: a cross-sectional study. BioMed Central AIDS Research Therapy. 2014;11(1):9

15. Meriki HD, Tufon KA, Afegenwi MH, Nyindem BA, Atanga PN, Anong DN, Cho-Ngwa F, Nkuo-Akenji T. Immuno-haematologic and virologic responses and predictors of virologic failure in HIV-1 infected adults on first-line antiretroviral therapy in Cameroon. BioMed Central Infectious Diseases Poverty. 2014;3(1):5.

16. Greig JE, du Cros PA, Mills C, Ugwoeruchukwu W, Etsetowaghan A, Grillo A, Tayo-Adetoro A, Omiyale K, Spelman T, O'Brien DP. Predictors of raised viral load during antiretroviral therapy in patients with and without prior antiretroviral use: a cross-sectional study. PLoS One. 2013;8(8):e71407.

17. $\mathrm{WHO}$. Consolidated guidelines on the use of antiretroviral drugs for treating and preventing HIV infection: recommendations for a public health approach- 2nd ed. Geneva, WHO, 2016

18. Kwobah CM, Mwangi AW, Koech JK, Simiyu GN, Siika AM. Factors associated with first-line antiretroviral therapy failure amongst HIV-infected African patients: a case-control study. World J AIDS. 2012;2(4):271-8.

19. Mingbunjerdsuk $P$, Asdamongkol N, Sungkanuparph S. Factors associated with immunological discordance in HIV-infected patients receiving antiretroviral therapy with complete viral suppression in a resource-limited setting. Japanese J Infectious Dis. 2015;68(4):301-4.

20. Liégeois F, Vella C, Eymard-Duvernay S, Sica J, Makosso L, Mouinga-Ondémé A, Mongo AD, Boué V, Butel C, Peeters M, Gonzalez JP. Virological failure rates and HIV-1 drug resistance patterns in patients on first-line antiretroviral treatment in semirural and rural Gabon. J Int AIDS Society. 2012;15(2):17985

21. Kassa D, Gebremichael G, Alemayehu Y, et al. Virologic and immunologic outcome of HAART in Human Immunodeficiency Virus (HIV)-1 infected patients with and without tuberculosis (TB) and latent TB infection (LTBI) in Addis Ababa, Ethiopia. AIDS Res Ther. 2013;10:18. https://doi.org/10.1186/ 1742-6405-10-18.

22. JORGE, Alave R., et al. Risk factors associated with virologic failure in HIVinfected patients receiving antiretroviral therapy at a public hospital in Peru. Revista chilena de infectologia: organo oficial de la Sociedad Chilena de Infectologia, 2013, 30.1: 42.

23. SANG, R. K. A.; MIRUKA, F. O. Factors associated with virologic failure amongst adults on antiretroviral therapy in Nyanza Region, Kenya. IOSR J Dental Med Sci, 2016, 15.7: 108-121.

24. Putting HIV and HCV to the test: a product guide for point-of-care CD4 and laboratory-based and point-of-care virological HIV and HCV tests. Geneva: Médecins Sans Frontieres. 2015. $2^{\text {nd }}$ edition -reported on 14 july 2015.
25. Braithwaite RS, Nucifora KA, Toohey C, Kessler J, Uhler LM, Mentor SM, Keebler D, Hallett T. How do different eligibility guidelines for antiretroviral therapy affect the cost-effectiveness of routine viral load testing in subSaharan Africa? AIDS (London, England). 2014;28(1):S73-23.

26. Estill J, Egger M, Johnson LF, Gsponer T, Wandeler G, Davies MA, Boulle A, Wood R, Garone D, Stringer JS, Hallett TB, Keiser O. leDEA Southern Africa Collaboration. Monitoring of antiretroviral therapy and mortality in HIV programmes in Malawi, South Africa and Zambia: mathematical modelling study. PLoS One. 2013;8(2):e57611. https://doi.org/10.1371/journal.pone. 0057611.

27. Keebler D, Revill P, Braithwaite S, Phillips A, Blaser N, Borquez A, Cambiano V, Ciaranello A, Estill J, Gray R, Hill A. Cost-effectiveness of different strategies to monitor adults on antiretroviral treatment: a combined analysis of three mathematical models. Lancet Global Health. 2014;2(1):e35-43.

28. World Health Organization. Antiretroviral therapy (ART) coverage among all age groups. World Health Organization. Available from https://www.who. int/data/gho/hiv/epidemic response/ART/en/.

29. Consolidated Guidelines on the Use of Antiretroviral Drugs for Treating and Preventing HIV Infection: Recommendations for a Public Health Approach. 2nd edition. Geneva: World Health Organization; 2016. Available from: https://www.ncbi.nlm.nih.gov/books/NBK374294/.

30. Shamseer L, Moher D, Clarke M, Ghersi D, Liberati A, Petticrew M, Shekelle P, Stewart LA. Preferred reporting items for systematic review and metaanalysis protocols (PRISMA-P) 2015: elaboration and explanation. Brit Med J. 2015;349:97647.

31. Sterne JA, Hernán MA, Reeves BC, Savović J, Berkman ND, Viswanathan M, Henry D, Altman DG, Ansari MT, Boutron I, Carpenter JR. ROBINS-I: a tool for assessing risk of bias in non-randomised studies of interventions. Brit Med J. 2016;355:i4919.

32. Higgins JP, Thompson SG, Deeks JJ, Altman DG. Measuring inconsistency in meta-analyses. Brit Med J. 2003;327(7414):557.

33. Egger M, Smith GD, Schneider M, Minder C. Bias in meta-analysis detected by a simple, graphical test. British Medical Journal. 1997 Sep 13;315(7109): 629-34.

34. Babo YD, Alemie GA, Fentaye FW. Predictors of first-line antiretroviral therapy failure amongst HIV-infected adult clients at Woldia Hospital, Northeast Ethiopia. PloS one. 2017;12(11):e0187694. https://doi.org/10.1371/ journal.pone.0187694.

35. Bayu B, Tariku A, Bulti AB, Habitu YA, Derso T, Teshome DF. Determinants of virological failure among patients on highly active antiretroviral therapy in University of Gondar Referral Hospital, Northwest Ethiopia: a case-control study. HIV/AIDS (Auckland, NZ). 2017;9:153.

36. Enderis BO, Hebo SH, Debir MK, Sidamo NB, Shimber MS. Predictors of time to first line antiretroviral treatment failure among adult patients living with HIV in public health facilities of Arba Minch Town, Southern Ethiopia. Ethiopian Journal of Health Sciences. 2019;29(2):175.

37. Bisson GP, Rowh A, Weinstein R, Gaolathe T, Frank I, Gross R. Antiretroviral failure despite high levels of adherence: discordant adherence-response relationship in Botswana. J Acquir Immune Defic Syndr (1999). 2008;49(1):107.

38. Fatti G, Grimwood A, Nachega JB, Nelson JA, LaSorda K, van Zyl G, Grobbelaar N, Ayles H, Hayes R, Beyers N, Fidler S. Better virological outcomes among people living with human immunodeficiency virus (HIV) initiating early antiretroviral treatment (CD4 counts $\geq 500$ cells $/ \mathrm{mm}^{3}$ ) in the HIV prevention trials network 071 (PopART) trial in South Africa. Clin Infectious Dis. 2020;70(3):395-403.

39. Ford N, Darder M, Spelman T, Maclean E, Mills E, Boulle A. Early adherence to antiretroviral medication as a predictor of long-term HIV virological suppression: five-year follow up of an observational cohort. PloS one. 2010; 5(5):e10460. https://doi.org/10.1371/journal.pone.0010460.

40. Gunda DW, Kilonzo SB, Mtaki T, Bernard DM, Kalluvya SE, Shao ER. Magnitude and correlates of virological failure among adult HIV patients receiving PI based second line ART regimens in north western Tanzania; a case control study. BMC infectious diseases. 2019;19(1):235.

41. Haile D, Takele A, Gashaw K, Demelash H, Nigatu D. Predictors of treatment failure among adult antiretroviral treatment (ART) clients in Bale zone hospitals, south eastern Ethiopia. PloS One. 2016;11(10):e0164299. https:// doi.org/10.1371/journal.pone.0164299.

42. Hailu GG, Hagos DG, Hagos AK, Wasihun AG, Dejene TA. Virological and immunological failure of HAART and associated risk factors among adults and adolescents in the Tigray region of Northern Ethiopia. PloS One. 2018; 13(5) 
43. Izudi J, Alioni S, Kerukadho E, Ndungutse D. Virological failure reduced with HIV-serostatus disclosure, extra baseline weight and rising CD4 cells among HIV-positive adults in north-western Uganda. BMC infectious diseases. 2016; 16(1):614.

44. Karade SK, Ghate MV, Chaturbhuj DN, Kadam DB, Shankar S, Gaikwad N, Gurav S, Joshi R, Sane SS, Kulkarni SS, Kurle SN, Paranjape RS, Rewari BB, Gangakhedkar RR. Cross-sectional study of virological failure and multinucleoside reverse transcriptase inhibitor resistance at 12 months of antiretroviral therapy in Western India. Medicine (Baltimore). 2016;95(37): e4886. https://doi.org/10.1097/MD.0000000000004886.

45. Lay P, An S, Soeung S, Srey PS, Thai S, Lynen L, Griensven J. Ten year experience with antiretroviral treatment in Cambodia: trends in patient characteristics and treatment outcomes. PloS One. 2017;12(11):e0185348. https://doi.org/10.1371/journal.pone.0185348.

46. Ndahimana JD, Riedel DJ, Mwumvaneza M, Sebuhoro D, Uwimbabazi IC Kubwimana M, Mugabo J, Mulindabigwi A, Kirk C, Kanters S, Forrest J. Drug resistance mutations after the first 12 months on antiretroviral therapy and determinants of virological failure in Rwanda. J Tropical Med Int Health. 2016;21(7):928-35.

47. Ahmed M, Merga $\mathrm{H}$, Jarso $\mathrm{H}$. Predictors of virological treatment failure among adult HIV patients on first-line antiretroviral therapy in Woldia and Dessie hospitals, Northeast Ethiopia: a case-control study. BMC Infectious Diseases. 2019;19(1):305.

48. Lay P, An S, Soeung S, Srey PS, Thai S, Lynen L, et al. Ten year experience with antiretroviral treatment in Cambodia: trends in patient characteristics and treatment outcomes. PLoS One. 2017;12(11):1-16.

49. Chakraborty A, Hershow RC, Qato DM, Stayner L, Dworkin MS. Adherence to antiretroviral therapy among HIV patients in India: a systematic review and meta-analysis. AIDS Behav. 2020;24(7):2130-48.

50. AIDSinfo. Guidelines for the use of antiretroviral agents in HIV-1-infected adults and adolescents. 2017.

51. Matare T, Shambira G, Gombe N, Tshimanga M, Bangure D. Factors associated with human immunodeficiency virus first-line treatment failure in Zvishavane District, Zimbabwe, 2014. Austin J HIV/AIDS Research. 2015;2(1): 1010.

52. Assemie MA, Alene M, Ketema DB, Mulatu S. Treatment failure and associated factors among first line patients on highly active antiretroviral therapy in Ethiopia: a systematic review and meta-analysis. Global Health Research Policy. 2019;4(1):1-0.

53. Thao VP, Quang VM, Wolbers M, Anh ND, Shikuma C, Farrar J, et al. Secondline HIV therapy outcomes and determinants of mortality at the largest HIV referral Center in Southern Vietnam. Medicine. 2015;94(43).

54. Zaragoza-Macias E, Cosco D, Nguyen ML, Del Rio C, Lennox J. Predictors of success with highly active antiretroviral therapy in an antiretroviral-naive urban population. AIDS Research and Human Retroviruses. 2010;26(2):133-8.

55. Krüsi A, Milloy MJ, Kerr T, Zhang R, Guillemi S, Hogg R, Montaner J, Wood E. Ongoing drug use and outcomes from highly active antiretroviral therapy among injection drug users in a Canadian setting. Antiviral therapy. 2010; 15(5):789.

56. Nachega JB, Marconi VC, van Zyl GU, Gardner EM, Preiser W, Hong SY, et al. HIV treatment adherence, drug resistance, virologic failure: evolving concepts. Infect Disord-Drug Targets (Formerly Current Drug TargetsInfectious Disorders). 2011;11(2):167-74.

57. Olowookere SA, Adewole IF. Effects of adherence to antiretroviral therapy on body mass index, immunological and virological status of Nigerians living with HIV/AIDS. Alexandria J Med. 2016;52(1):51-4.

\section{Publisher's Note}

Springer Nature remains neutral with regard to jurisdictional claims in published maps and institutional affiliations.

Ready to submit your research? Choose BMC and benefit from:

- fast, convenient online submission

- thorough peer review by experienced researchers in your field

- rapid publication on acceptance

- support for research data, including large and complex data types

- gold Open Access which fosters wider collaboration and increased citations

- maximum visibility for your research: over $100 \mathrm{M}$ website views per year

At BMC, research is always in progress.

Learn more biomedcentral.com/submissions 